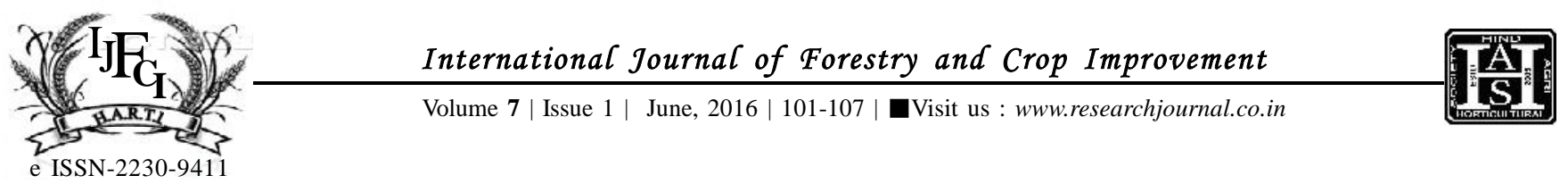

RESEARCH ARTICLE

DOI: $10.15740 / \mathrm{HAS} / \mathrm{IJFCI} / 7.1 / 101-107$

\title{
An economic analysis of production of pomegranate in middle Gujarat
}

\author{
SURAJKUMAR K. PATEL AND R. S. PUNDIR
}

\begin{abstract}
The area and production of pomegranate in Gujarat is increasing noticeably from last decade.The economic viability of pomegranate cultivation has been studied in middle Gujarat. The study was based on the data collected from 90 Pomegranate grower spread over total 9 blocks of the Vadodara, Chhota udepur and Kheda district for the agricultural year 201314. Pomegranate cultivation involves high initial investment, but same time annual net return was also high. The establishment cost of pomegranate orchard was found to be Rs. 81063. The average per ha net return was found Rs. 88686 and average production was found $5482 \mathrm{~kg}$ per hectare. The value of economic parameters, viz., NPV, BCR, IRR and PBP was found Rs. 993842, $3.07,47.66$ and 58 month, respectively at 10 per cent discount rate. In all the varying situations of cost and return in sensitivity analysis, values of all these economic parameters satisfied the acceptance rules for investment proposition. This indicates that in varying situations of cost and return, the economic viability of investment on the pomegranate cultivation was stable and certain.
\end{abstract}

KEY WORDS : Economic analysis, Production, Pomegranate

HOW TO CITE THIS ARTICLE : Patel, Surajkumar K. and Pundir, R.S. (2016). An economic analysis of production of pomegranate in middle Gujarat. Internat. J. Forestry \& Crop Improv., 7 (1) : 101-107, DOI: 10.15740/HAS/IJFCI/7.1/101-107.

Article Chronical : Received : 21.03.2016; Revised : 23.04.2016; Accepted : 25.05.2016

Address of the Correspondence : R. S. PUNDIR, Agribusiness Economics and Policies, International Agribusiness Management Institute, Anand Agricultural University, ANAND (GUJARAT) INDIA Email: rspundir@aau.in

Address of the Coopted Authors : SURAJKUMAR K. PATEL, Agribusiness Economics and Policies, International Agribusiness Management Institute, Anand Agricultural University, ANAND (GUJARAT) INDIA 